\title{
Stock Returns and the Term Structure
}

\section{Citation}

Campbell, John Y. 1987. Stock returns and the term structure. Journal of Financial Economics 18, no. 2: 373-399.

\section{Published Version}

http://dx.doi.org/10.1016/0304-405X(87)90045-6

\section{Permanent link}

http://nrs.harvard.edu/urn-3:HUL.InstRepos:3207699

\section{Terms of Use}

This article was downloaded from Harvard University's DASH repository, and is made available under the terms and conditions applicable to Other Posted Material, as set forth at http:// nrs.harvard.edu/urn-3:HUL.InstRepos:dash.current.terms-of-use\#LAA

\section{Share Your Story}

The Harvard community has made this article openly available.

Please share how this access benefits you. Submit a story.

Accessibility 
NBER WORKING PAPER SERIES

STOCK RETURNS AND THE TERM STRUCTURE

John Y. Campbell

Working Paper No. 1626

\author{
NATIONAL BUREAU OF ECONOMIC RESEARCH \\ 1050 Massachusetts Avenue \\ Cambridge, MA 02138 \\ June 1985
}

This paper is based on Chapter 5 of my Yale PhD dissertation, "Asset Duration and Time-Varying Risk Premia." I am grateful to Robert Engle, Huston McCulloch, Frederic Mishkin, Robert Shiller, Kenneth Singleton and James Tobin, and seminar participants at Columbia and Princeton Universities and the National Bureau of Economic Research, for helpful comments. I am responsible for any remaining errors. The research reported here is part of the NBER's research program in Financial Markets and Monetary Economics. Any opinions expressed are those of the author and not those of the National Bureau of Economic Research. 
NBER Working Paper \#1626

June 1985

Stock Returns and the Term Structure

\section{ABSTRACT}

It is well known that in the postwar period stock returns have tended to be low when the short term nominal interest rate is high. In this paper I show that more generally the state of the term structure of interest rates predicts stock returns. Risk premia on stocks appear to move closely together with those on 20-year Treasury bonds, while risk premis on Treasury bills move somewhat independently. Average returns on 20-year bonds have been very low relative to average returns on stocks.

I use these observations to test some simple asset pricing models. First I consider latent variable models in which betas are constant and risk premia vary with expected returns on a small number of unobservable hedge portfolios. The data strongly reject a single-latent-variable model.

The last part of the paper examines the relationship between conditional means and variances of returns on bills, bonds and stocks. Bill returns tend to be high when their conditional variance is high, but there is a perverse negative relationship between stock returns and their conditional variance. A model is estimated which assumes that asset returns are determined by their time-varying betas with a fixed-weight "benchmark" portfolio of bills, bonds and stocks, whose return is proportional to its conditional variance. This portfolio is estimated to place almost all its weight on bills, indicating that uncertainty about nominal interest rates is important in pricing both short-and long-term assets.

John Y. Campbel1

Department of Economics

Dickinson Hall

Princeton University

Princeton, N J 08544

(609) 452-4011 
In recent years a great deal of effort has been expended in testing rational expectations models of long-term asset prices. Such models state that the rationally expected returns on some set of assets, measured over some time interval, differ across assets only by a constant. Typically one asset in the set has a (nominal) return which is known in advance, so the model implies that expected returns on all the other assets are equal to this known return, plus a constant. The difference between two expected returns is often called a "risk premi$u^{\prime \prime}$, and expectations models state that risk premia are constant through time. ${ }^{1}$

Two particularly well-known expectations models concern the term structure of interest rates, and the relationship between stock returns and interest rates. The expectations theory of the term structure states that expected returns on bonds and bills of all maturities are equal except for a constant. The expectations theory for stock returns and interest rates, as described informally by Fama and Schwert [1977], states that expected nominal stock returns equal the nominal Treasury bill rate, plus a constant.

Fama and Schwert showed that in postwar U.S. data the expectations theory for stock returns and interest rates is strongly rejected. When monthly stock returns are regressed on the 1-month Treasury bill rate, the estimated coefficient is about -5 rather than +1 as predicted by the theory. Fama and schwert attributed their results to a negative impact of inflation on stock returns. ${ }^{2}$

1 Expectations models as defined here are less restrictive than the models considered by Cox, Ingersoll and Ross [1981] and LeRoy [1982a], which state that risk premia are constant at zero. 
The expectations theory of the term structure has also been rejected in recent empirical work. Shiller, Campbell and Schoenholtz [1983], Campbell and Shiller [1984] and Mankiw and Summers [1984] showed that the spread between the long bond yield and the short interest rate predicts excess returns on long bonds. Campbell [1984a] shows that the spread between 2 - and 1 -month bill rates, and the lagged excess return on 2-month bills over 1-month bills, also have predictive power for excess returns in the term structure.

These findings are not the result of data mining, but rather are based on careful consideration of the properties of the expectations theory of the term structure. Campbell [1984a] derives an expression for the yield spread between long and short rates as a weighted sum of the expected change in the long rate, and the risk premium on the long bond in the next period. Similarly, the spread between a 2-period and 1-period rate is a weighted sum of the expected change in the 1-period rate and the expected excess return on a 2-period bond in the next period. Thus if the expectations theory is false, and risk premia vary through time, yield spreads will reflect these variations. The lagged excess return on 2 -month bills will be a good proxy for the expected excess return on 2 -month bills if risk premia move through time in a persistent manner, and will be a good proxy for excess returns on bonds if in addition there is correlation of risk premia across maturities. ${ }^{3}$

2 However the theoretical analysis in the literature explains a negative impact of an inflation surprise on contemporaneous stock returns, rather than a negative relation between inflation and the risk premium on stock.

3 Lagged excess bond returns are too volatile to be good proxies for 
The first contribution of this paper is to show that the variables which have been used as proxies for risk premia on 20-year Treasury bonds, also predict excess stock returns. " This fact is documented in section 1 , and suggests an interpretation of the results of Fama and Schwert: risk premia on bonds and stocks move together. Section 1 also shows that the behavior of excess returns on 2-month Treasury bills is strikingly different. Although excess returns on 2-month bills are highly predictable, the estimated risk premia are only weakly correlated with estimated risk premia for the two longterm assets.

Despite their common movement, risk premia on bonds and stocks do differ in some important respects. The estimated standard deviations of stock risk premia are considerably larger than those of bond risk premia, while the mean risk premia on these assets have opposite signs. In the 1959-78 period, mean excess returns on bonds were negative at $-1.605 \%$, while mean excess returns on stocks were highly positive at $3.353 \%$. 2-month bills fell in between with mean excess returns of $0.234 \%$. Updating to 1983 , the means were $-2.485 \%, 3.896 \%$ and $0.378 \%$ respectively.

These observations offer an opportunity to test asset pricing models in ways which are not possible when time variation in expected returns is ignored. They also challenge a variety of informal macroeconomic explanations which have been proposed for risk premia.

risk premia.

4 Keim and Stambaugh [1984] independently noted this phenomenon, using a different set of information variables. See also Huizinga and Mishkin [1984]. 
Fama [1976] attributed time-varying risk premia in the term structure of Treasury bill returns to time variation in uncertainty about future nominal short rates (which he equated with future expected inflation rates). Excess returns on bills, bonds and stock all tend to be low when there is a positive innovation in short rates, so they all have "betas" on short rates of the same sign. Time variation in uncertainty about short rates would cause risk premia to move together. The persistence of the stochastic process for short interest rates gives long bonds a high beta on short rate innovations, and thus explains why estimated bond risk premia have a high standard deviation relative to bill premia. The high beta of stock returns remains something of a mystery in this framework, although Fama [1981], Schwert [1981], Geske and Roll [1983] and others have tried to explain it.

One difficulty with this simple model is that it implies that risk premia on bills and bonds should move together, and bonds should have high average returns. In Fama's words, when the short rate process is persistent,

\footnotetext{
"uncertainty about the change in the spot rate creates more uncertainty in a bill's premium the longer the maturity of the bill. If this source of uncertainty is positively associated with the types of risks that the market compensates, then expected premiums on bills will be an increasing function of maturity, and any changes through time in the degree of uncertainty about changes in spot rates will have a greater effect on a bill's expected premium the longer the maturity of the bill."

[Fama, 1976, p. 436]
} 
Another explanation for risk premia, expounded for the stock market by Pindyck [1984], is that there is time variation in uncertainty about real output and thus about real interest rates and stock dividends. It is natural to presume that stocks have a high positive beta on output surprises, and thus that output uncertainty raises expected excess stock returns. Campbel1 [1984b] shows that when output follows a covariance stationary stochastic process, in a simple "representative agent" exchange model, output uncertainty also raises expected excess returns on bonds of sufficiently long maturity.

A closely related model is the traditional 1-period CAPM where the market portfolio is taken to be the stock market. ${ }^{5}$ In this model, the risk premium on any asset is just the product of the asset's beta on stock returns, and the expected excess return on stocks. If bills and bonds have a positive beta on stocks, and the expected return on the market varies as in Merton [1980], then expected bill, bond and stock returns should move together. Here again, however, the low average returns on long bonds and the low correlation of expected bill returns with the other assets remain a mystery.

In the second half of this paper I use the observations of section 1 to evaluate simple explanations of time-varying risk premia of the sort just discussed. I do not relate risk premia to macroeconomic variables such as real consumption, unemployment, inflation or industrial production. This type of analysis is left for future research. Instead, I develop and test the restrictions of simple asset pricing models on the first and second moments of asset returns themselves.

5 Constantinides [1980] discusses conditions under which the CAPM will hold even in an intertemporal setting. 
The theoretical framework for all the models tested is a discrete time version of the intertemporal capital asset pricing model (ICAPM), in which asset prices are derived from the first order conditions of the intertemporal optimization problem of a representative consumer. The framework is laid out in Appendix A.

The analysis makes extensive use of the concept of the "benchmark portfolio". As defined by Hansen, Richard and Singleton, the benchmark portfolio is the portfolio whose return is the ratio of the discounted marginal utility of consumption next period to the marginal utility of consumption this period, divided by the conditional expectation of the square of this ratio. Any portfolio return which is perfectly conditionally correlated with the marginal utility of consumption next period, is perfectly conditionally correlated with the benchmark return. Under the ICAPM, any such return has the properties that its conditional mean and variance move approximately in proportion, and that conditional expectations of other returns can be determined from their "betas" with such a return in the manner familiar from the 1-period CAPM.

In section 2 of the paper I assume that the underlying sources of uncertainty are unobservable. In the context of the ICAPM, this is equivalent to assuming that the benchmark return is unobservable. Without observing the benchmark, one cannot test explanations of risk premia unless one makes some strong auxiliary assumptions. I assume that the benchmark portfolio places time-varying weights on a small number of "hedge portfolios", which are also unobservable but on which a11 assets have constant betas. Then changes in underlying uncertain- 
ties affect expected asset returns only by changing the expected returns on these hedge portfolios.

Models of this type seem to capture the spirit of the informal accounts of risk premia discussed above, in that movements in a few parameters drive expected returns on many assets at once. The data are restricted in this framework so long as there are more assets than hedge portfolios, and more information variables than hedge portfolios. Econometrically, the expected returns on hedge portfolios are "latent variables" driving risk premia. I show that the data strongly reject a single-latent-variable model with constant betas, and there is weak evidence against a two-latent variable model with constant betas. Thus changes in risk premia do not seem to be attributable solely to changes in a single variance parameter for interest rates, output or stock returns.

In section 3 I test the hypothesis that one of the assets studied in the paper, or some fixed-weight combination of them, is perfectly correlated with the benchmark return. This is an alternative way to model informal explanations of risk premia, which does not require the auxiliary assumption that betas are constant. The nominal interest rate uncertainty model, for example, suggests that the benchmark is perfectly correlated with the 2-month bill, since the unexpected return on this asset is just the innovation in the 1-month interest rate. The output uncertainty model suggests that the benchmark portfolio is perfectly correlated with the stock market.

I begin section 3 of the paper by examining the relationship between conditional means and variances of returns on bills, bonds and 
stocks. This is useful as a means of characterizing the data, and because if any one of these assets is perfectly correlated with the benchmark portfolio for the economy, then its expected return should move approximately in proportion with its conditional variance. I find that bill returns tend to be high when their conditional variance is high, but that the reverse is true for stocks. ${ }^{6}$

I go on to estimate and test a model which assumes that the benchmark portfolio places unknown fixed weights on bills, bonds and stocks. Expected returns on individual assets are assumed to be determined by their betas with this portfolio, whose conditional expected return is proportional to its conditional variance. Both betas and the conditional moments of the benchmark return are modelled as linear functions of information variables. The estimated portfolio places almost all its weight on 2 -month bills, indicating that interest rate uncertainty is indeed important in pricing both short- and long-term assets.

- The result for bills confirms the finding of Engle, Lilien and Robins [1985] who specify their model differently and use different data. 


\section{Regression Tests of Expectations Theories}

In Tables 1A through 1C I present regressions which test the expectations theories for 2-month bills, 20-year bonds, and stocks. In the first half of each table the sample period is 1959:2 through 1978:9; in the second half the regressions are repeated for the 1959:2 through 1983:11 period. The shorter sample corresponds to a period which is often thought of as a single "policy regime", and which has been extensively used in recent empirical studies of interest rate behavior (e.g. Huizinga and Mishkin [1984]). The longer sample includes recent data; in comparison with the earlier period, these are characterized principally by greater volatility in long bond yields. For a detailed explanation of data sources and transformations, see Appendix B.

In each table the excess return on 2-month bills, 20-year bonds or stock over 1-month bills is regressed on five sets of variables: a constant and the short interest rate in each row, alone (row 1), with the spread of the 2 -month rate over the 1 -month rate (row 2), with the spread of the 20-year bond rate over the 1 -month rate (row 3 ), with the lagged excess return on 2-month over 1-month bills (row 4), and with all the above (row 5).

The short rate is retained as an explanatory variable throughout, for two main reasons. First, the results of the paper can easily be compared with those of Fama and Schwert, and the question can be answered: is the predictive power of the short rate for stock returns robust, or is the short rate acting merely as a proxy for other term structure variables? Fama and Schwert's dependent variable is the 
holding return rather than the excess return on stock - that is, they do not subtract the 1 -month bill rate from the stock return - but the inclusion of the 1 -month bill rate in the regressions of this paper makes the results directly comparable. Secondly, with the short rate included the independent variables can be interpreted as elements of a vector of interest rates, minimally restricted. The 1-month, 2-month and 20-year rates are included without restrictions, and the first lags of the 1 -month and 2 -month rates are included with a single coefficient restriction by including the lagged excess return on 2 -month bills .

One possible problem with the use of the short rate as an explanatory variable is that it may be nonstationary in the sample period; if this is the case, then the asymptotic theory which underlies the statistical inference of the paper may be invalidated. However the regressions reported in Tables 1 were repeated excluding the short rate, and yielded essentially the same results.

Below each coefficient in the tables, two standard errors are reported. These do not rely on the assumption of the classical linear model that the equation error is homoskedastic, for this is not an implication of the expectations theory. The theory does not suggest that heteroskedasticity should take any particular form. Accordingly the first standard error presented in the tables is that of White [1980, 1984], which is based on an estimator of the covariance matrix of coefficient estimates which is consistent in the presence of heteroskedasticity of unknown form. ${ }^{7}$

7 I follow the ruling of McCulloch [1985] in my spelling of the word "heteros"'edasticity". The consistency of White's covariance matrix 
White's standard error is larger than the ordinary standard error, in a simple OLS regression, when the equation error variance is positively correlated with the square of the explanatory variable. Thus in row 4 of Table $1 \mathrm{~A}$, the explanatory variable is just the dependent variable lagged once; its variance is persistent through time, so White's standard error is about twice the ordinary standard error. For most other variables, White's standard error is close to the ordinary standard error and makes little difference to the significance level at which the expectations model is rejected.

MacKinnon and White [1984] and Chesher and Jewitt [1984] have recently examined the small-sample properties of White's covariance matrix estimator. Mackinnon and White propose an a1ternative estimator, based on a "jackknife" resampling scheme (Efron [1982]), which is asymptotically equivalent to White's estimator but which has superior finite-sample properties. This is the second standard error presented in Tables 1.

The jackknife standard error is always greater than White's standard error, but the difference is never greater than $7 \%$ of White's standard error. This relatively small difference suggests that although small sample problems are present, they are not very serious for these data. Accordingly sections 2 and 3 of the paper rely exclusively on asymptotic inference.

estimator depends on the assumption that the regressors and equation errors are jointly stationary or can be expressed as a joint mixing process, and on certain technical moment restrictions which $I$ assume are satisfied. 
A related indicator of small sample problems is the "maximum hat value". This is computed as Max $\left[h_{i i}\right]$, where $h_{i i}$ is the ${ }^{\prime}$ th diagonal element of $\mathrm{H}=\mathrm{X}\left(\mathrm{X}^{\prime} \mathrm{X}\right)^{-1} \mathrm{X}^{\prime}$. It is bounded above by one, and approaches zero asymptotically. Belsley, Kuh and Welsch [1980] discuss the maximum hat value as a diagnostic statistic for the presence of a single particularly influential observation in a regression, and Chesher and Jewitt [1984] show that large maximum hat values are associated with large biases in White's standard errors.

The maximum hat value is reported in each regression of Tables 1 as the first number in the last column. The regressions with a larger maximum hat value typically also display a greater difference between White's and the jackknife standard errors. Below the maximum hat value are significance levels, based on the White and jackknife covariance matrices respectively, for a test of the hypothesis that all coefficients except the constant are zero. The $\mathrm{R}^{2}$ and Durbin-Watson statistics are also reported for each regression.

In Table $1 \mathrm{~A}$ excess returns on 2-month bills are regressed on the various information variables. The main result for the sample period 1959-1978 (rows 1-5) is that the spread between 2- and 1-month bill rates, measured at the beginning of a month, has strong explanatory power for the excess return on 2 -month bills over the month. ${ }^{8}$ Over the full 1959-1983 sample, the short rate and the lagged excess return on

The coefficient of the spread in row 2 is 1.351 . Ignoring the presence of the short rate in the regression, it can be shown that the coefficient in a regression of the change in short rates on the change predicted by the term structure would be $1-(1.351 / 2)=0.325$. Fama [1984a] obtains a similar coefficient, and argues that this shows that the term structure has some ability to forecast changes in interest rates, even though the expectations theory is rejected. 
2-month bills also have explanatory power.

In Table $1 B$ the dependent variable is the excess return on 20-year bonds. The explanatory power of the information variables is far less impressive in this table. The spread between the 20-year bond rate and the 1 -month bill rate is significant at the $5 \%$ leve 1 in both sample periods; this result was obtained earlier by Shiller, Campbel1 and Schoenholtz [1983] and Campbell and Shiller [1984]. The lagged excess return on 2 -month bills is significant at the $5 \%$ leve 1 for the 1959-78 period, and the hypothesis that the information variables are jointly insignificant can be rejected using the White and jackknife standard errors at the $3.5 \%$ and $5.3 \%$ levels respectively. However when the sample is updated these results become much weaker.

In Table $1 \mathrm{C}$ the dependent variable is the excess return on common stock. The first row is the regression performed by Fama and Schwert [1977], and as in their paper the coefficient on the short rate is estimated significant at the $1 \%$ level and negative. ${ }^{9}$ In row 2 the 2-month spread is added; it has a positive coefficient but very weak explanatory power, and the short rate remains significant and negative. In rows 3 and 4 however, the 20-year spread and the lagged excess bill return have significant positive coefficients and render the short rate insignificant. The lagged excess bill return on its own explains $11 \%$ of the variation of stock returns in this period and has a jackknife $t$ statistic of almost 3 . The statistical significance of these explanatory variables is even stronger when the sample is updat-

S Fama and Schwert did not subtract the 1 -month bill rate from their dependent variable. Therefore in their regression the expectations theory implied a coefficient of +1 , whereas here it implies a zero coefficient. 
ed to 1959-83, although for this sample the short rate retains its significance at the $5 \%$ level when all other variables are included. In general the $R^{2}$ values for stock returns are about twice those for 20-year bond returns.

It is of interest to consider Tables $1 \mathrm{~A}, 1 \mathrm{~B}$ and $1 \mathrm{C}$ as a group. The pattern of significant coefficients in Table $1 \mathrm{~A}$ is quite different from the pattern in Tables $1 \mathrm{~B}$ or $1 \mathrm{C}$ : predictable excess returns on 2-month bills appear to move somewhat independently from risk premia on bonds or stocks. However the pattern of coefficients is similar in Tables $1 \mathrm{~B}$ and $1 \mathrm{C}$, suggesting that risk premia on bonds and stocks move together. In Table 2 I report the correlations of the fitted values from rows 5 of Tables 1A, 1B and 1C. In the 1959-78 period, estimated risk premia on bills and bonds have a positive correlation of 0.551 ; bill and stock risk premia have a correlation of 0.285 ; but bond and stock risk premia have an extremely high correlation of 0.864 . The estimated standard deviations of risk premia on bills, bonds and stock are $0.231,5.938$ and 17.024 respectively. In 1959-83, the correlations are measured at $0.029,0.321$ and 0.778 , while the standard deviations are $0.465,8.904$ and 16.143 .

Of course, there may be other variables known to the market which explain excess returns on bills, bonds and stock and which are omitted from the regressions of Table 1 . The effects of these variables could reduce the estimated correlations of risk premia. However they could only do so by increasing the estimated standard deviations of risk premia, which are already quite striking. ${ }^{10}$

10 Consider adding "omitted information" terms to the estimated risk premia on bonds and stock. Suppose these are perfectly negatively 
Table 2 also presents summary statistics for ex post returns on bills, bonds and stock. The main points to note are that ex post bill, bond and stock returns have rather low correlations, ${ }^{11}$ and that the variance of ex post bond returns increases dramatically when 1979-83 is added to the sample. This may help to explain the weak results for the full sample period in Table $1 \mathrm{~B}$.

In conclusion, this section has presented evidence that there are predictable movements through time in excess returns on bills, bonds and stock. These movements are partially captured by a variety of term structure variables, which add considerably to the predictive power of the short interest rate alone. The evidence for predictability of bill and stock returns is very strong, while the results for bonds are much weaker. However, predictable movements in bond and stock returns are highly correlated, while risk premia on bills move somewhat independently. Mean bond returns are low compared to mean bill and stock returns. In the remainder of the paper, these observations are used to test some simple asset pricing models.

correlated, and have variances proportional to the variances of the estimated risk premia. To eliminate the correlation of risk premia, the ratio of the variance of the omitted terms to the variance of the estimated risk premia would have to equal the estimated correlation of risk premia. Thus in the case of bonds and stock in 1959-78, the variance of risk premia would have to be at least 1.864 times as large as estimated if the risk premia were in fact uncorrelated.

11 This observation for bills and bonds contradicts a popular impression that short and long term interest rates "move together" over short intervals. 


\section{Latent Variable Mode1s for Predictable Asset Returns}

In this section I test the hypothesis that the predictable excess returns uncovered in section 1 are driven by a small number of unobservable latent variables. This hypothesis can be interpreted atheoretically, as a way of characterizing the extent to which predictable asset returns "move together"; or it can be interpreted as a specialization of the intertemporal capital asset pricing model (ICAPM) in which assets have constant betas on a small number of unobservable hedge portfolios. A more extensive discussion of the theoretical interpretation is given in Appendix A of the paper.

The ICAPM with $\mathrm{K}$ hedge portfolios, on which assets have constant betas, places the following restriction on the excess return on a particular asset i, eh it $^{12}$

(2.1) E[eh $\left.{ }_{i t} \mid x_{t}\right]=\sum_{k=1}^{K} \beta_{i k} E\left[e h_{k t} \mid x_{t}\right] \quad i=1 \ldots I$

Here $\beta_{i k}$ is the "beta" of excess return $i$ with the $k$ 'th hedge portfo1io, $\operatorname{Cov}_{t}\left(e_{i t}, e_{k t}\right) / \operatorname{Var}_{t}\left(e h_{k t}\right)$, and $x_{t}$ is the vector of information variables $x_{1 t}, \ldots x_{J t}$. $E\left[e_{k t} \mid x_{t}\right]$ may be written as $\theta_{k 1} x_{1 t}+\ldots+$ $\theta_{k J} x_{J t}$. The returns on the $K$ hedge portfolios are assumed to be unobservable in both their expected and unexpected components; that is, they are treated as latent variables.

12 This excess return need not be the excess over the risk-free rate. Without loss of generality, the $\mathrm{K}$ hedge portfolio returns are as sumed to be orthogonal. See Appendix A for further details. 
Following Hansen and Hodrick [1983] and Gibbons and Ferson [1983], I consider the implications of (2.1) for the system of I regression equations

(2.2) $\quad \mathrm{eh}_{t}=A \mathrm{x}_{t}+\mathrm{v}_{\mathrm{t}}$

$$
\text { where } \begin{aligned}
e{ }^{\prime}{ }_{t} & =\left[\begin{array}{llll}
e_{1 t} & \ldots & e h_{I t}
\end{array}\right] \\
x^{\prime}{ }_{t} & =\left[\begin{array}{llll}
x_{1 t} & \ldots & x_{J t}
\end{array}\right] \\
v^{\prime} & =\left[\begin{array}{lll}
v_{1 t} & \ldots & v_{I t}
\end{array}\right] \\
A & =\left[\begin{array}{ll}
\alpha_{i j}
\end{array}\right]
\end{aligned}
$$

The model (2.1) implies

$$
\text { (2.3) } \quad \alpha_{i j}=\sum_{k=1}^{K} \beta_{i k} \theta_{k j}
$$

where $\beta_{i k}$ and $\theta_{k j}$ are not observable directly. $K^{2} \beta$ coefficients may be normalized: for asset 1 , the betas may be assumed to be $\beta_{11}=1$, $\beta_{12}=0, \ldots, \beta_{1 \mathrm{~K}}=0$, for asset $2, \beta_{21}=0, \beta_{22}=1, \ldots, \beta_{2 \mathrm{~K}}=0$, and so on through asset $\mathrm{K}$ for which $\beta_{\mathrm{KK}}=1$. There are $\mathrm{IK}-\mathrm{K}^{2}$ remaining free $\beta^{\prime} s$, and JK free $\theta^{\prime} s$. There are IJ coefficients altogether in the matrix $A$, so $(I-K)(J-K)$ coefficients are restricted. Thus as stated in the introduction to the paper, the model places over-identifying restrictions on the data so long as the number of latent variables $K$ is strictly less than the number of assets $I$ and the number of information variables $\mathrm{J}$.

The implications of the model are particularly clear in the case of a single latent variable. Here $K=1$, we can drop the $k$ subscript and write $\alpha_{i j}=\beta_{i} \theta_{j}$, and the system (2.2) can be written as 
$(2.4)\left[\begin{array}{c}\text { eh } \\ \text { eht } \\ \cdot{ }_{2 t} \\ \cdot \\ \text { eh } \\ \text { It }\end{array}\right]=\left[\begin{array}{lllll}\beta_{1} \theta_{1} & \beta_{1} \theta_{2} & \cdots & \cdot & \beta_{1} \theta_{J} \\ \beta_{2} \theta_{1} & \beta_{2} \theta_{2} & \cdot & \cdot & \beta_{2} \theta_{J} \\ \cdot & \cdot & & \cdot \\ \cdot & \cdot & & \cdot \\ \beta_{I} \theta_{1} & \beta_{I} \theta_{2} & \cdots & \cdot & \beta_{I} \theta_{J}\end{array}\right]\left[\begin{array}{c}x_{1 t} \\ x_{2 t} \\ \cdot \\ \cdot \\ x_{J t}\end{array}\right]+\left[\begin{array}{c}v_{1 t} \\ v_{2 t} \\ \cdot \\ \cdot \\ v_{J t}\end{array}\right]$

$\beta_{1}$ is normalized to equal unity, so the first row of $A$ estimates the $\theta$ coefficients, the first column estimates the other $\beta$ coefficients, and the lower right-hand block is restricted. The single-latent-variable model restricts the data with as few as 2 asset returns and 2 information variables. It states that expected excess returns on all assets move in proportion with one another: that is, they are perfectly correlated (positively or negatively); the absolute values of their means are proportional to their standard deviations; and if two expected excess returns are positively correlated, their means have the same sign.

In Table 2 we have-already displayed summary statistics for measures of expected excess returns (the projections of excess returns on a subset of the market's information). Table 2 suggests that a single-factor model is far from an adequate description of expected returns on bills, bonds and stock. The correlations of the ex ante bill return with the ex ante bond and stock returns are only 0.551 and 0.285 respectively in the $1959-78$ period, and 0.029 and 0.321 respectively in the 1959-83 period. The ex ante bond and stock returns are highly positively correlated, but the mean bond return is negative while the mean stock return is positive. 
Of course, the statistics in Table 2 do not take any account of uncertainty in the underlying estimates in Table 1. In Table 3 I present formal test statistics for the hypothesis that restrictions (2.3) with $\mathrm{K}=1$ apply to the system of regression equations (2.2), where all explanatory variables from Table 1 are included in the test. The restricted system of equations was estimated by the Generalized Method of Moments (GMM) procedure (Hansen [1982], Hansen and Singleton [1982]), which allows for the presence of conditional heteroskedasticity. ${ }^{13}$ Hansen's Chi-square statistic was used to test the nonlinear cross-equation restrictions (2.3).

The Chi-square statistics, degrees of freedom and associated significance levels are displayed in Table 3 for both sample periods and al1 combinations of assets (bills-bonds-stock, bills-bonds, billsstock and bonds-stock). In both sample periods the single latent variable model can be rejected at the $1 \%$ level when all three assets are included in the test. In the longer period, bond returns contain no information which contributes to this rejection, since the tests which use bonds and bills or bonds and stocks alone do not reject. For the shorter period, there is some information in bond returns: the single latent variable model can be rejected at the $2.1 \%$ level using bills and bonds alone, and at the $7.9 \%$ level using bonds and stocks alone.

13 This is important since in the ICAPM variations in expected returns on hedge portfolios will generally be associated with variations in the conditional covariance matrix of asset returns. 
Given these results, a natural further step is to estimate and test a model with two unobservable latent variables. ( $K=2$ is the largest number of latent variables for which data on three asset returns are restricted). For the shorter sample period in Table 3, there is weak evidence against such a model; it is rejected at the $8.0 \%$ level. For the longer period, the significance of the Chi-square statistic is only $36.6 \%$. This is unsurprising since we have already noted that there is little information in bond returns for the longer period and the two other asset returns just suffice to identify two latent variables. Coefficient estimates and standard errors for the two latent variable model are also presented in Table 3. 


\section{Predictable Asset Returns With an Observable Benchmark Portfolio}

In this section I ask whether the predictable movements of excess returns uncovered in section 1 are associated with changes in the covariance matrix of ex post returns on bills, bonds and stock. As in the previous section, the results can be interpreted atheoretically, as an exploratory analysis of the second moments of returns in relation to information variables; or they can be interpreted as testing a particular specialization of the ICAPM.

The specialization I consider here relies on two strong assumptions. First, I assume either that a portfolio perfectly correlated with the benchmark, along with a riskfree interest rate, is known and observable; or that it places fixed weights on a known and observable set of assets, but that these weights must be estimated from the data. Secondly, I replace the assumption of the previous section that assets' betas are constant with the somewhat weaker assumption that betas are exact linear functions of a known set of information variables. That is, no other variables in the market's information set and no nonlinear functions of the information variables appear in the expressions for betas. Under these two assumptions, a particularly simple test of the ICAPM is possible and can be conducted using data on one or multiple assets.

As shown in more detail in Appendix A, the ICAPM implies that the conditional expectation of the excess return eh $z t$, on a portfolio perfectly conditionally correlated with the benchmark, is approximately proportional to its conditional variance. ${ }^{14}$ That is, we have the two-

14 The approximation arises from the use of a discrete time rather 
equation system

(3.1) $\quad$ eh ${ }_{z t}=\sum_{j=1}^{J} \alpha_{j} x_{j t}+u_{z t}$

$$
\operatorname{eh}_{z t}{ }^{2}=\left[\sum_{j=1}^{J} \alpha_{j} x_{j t}\right]^{2}+f\left[\sum_{j=1}^{J} \alpha_{j} x_{j t}\right]+v_{z t}
$$

Here the conditional expectation of $\mathrm{eh}_{z t}$ is written as a linear function of the information variables $x_{j t}$ (as in the previous section). The $\alpha_{j}$ coefficients define the conditional expected return, and $f$ is the coefficient of proportionality relating conditional first and second moments. $f$ is determined by the relation between $\mathrm{eh}_{z t}$ and $\mathrm{eh}_{\mathrm{bt}}$, the benchmark itself: we have $\mathrm{eh}_{z t}=(-1 / f) \mathrm{eh}_{\mathrm{bt}}$. One expects to find $f$ positive for the assets studied in this paper, since their returns seem likely to be positively correlated with consumption and thus negatively correlated with its marginal utility and the benchmark return. The errors $u_{z t}$ and $v_{z t}$ are orthogonal to the vector $x_{t}$, and are related by

$u_{z t}^{2}=f\left[\sum_{j=1}^{J} \alpha_{j} x_{j t}\right]+2 u_{z t}\left[\sum_{j=1}^{J} \alpha_{j} x_{j t}\right]+v_{z t}$.

The system (3.1) suggests a way to evaluate the simple ideas outlined in the introduction, which stressed output variability or interest rate variability as sources of time-varying risk premia on bills, bonds and stock. These explanations of risk premia can be treated as

than a continuous time formulation of the ICAPM. 
statements that certain portfolios are perfectly conditionally correlated with the benchmark portfolio. Thus the output variability model suggests a version of (3.1) in which the stock market has this property (as in tests of the 1-period CAPM in which the stock market is taken to be the market portfolio). The interest rate variability model suggests a version in which the 2 -month bill is perfectly conditionally correlated with the benchmark (since the unexpected component of the 1 -month return on a 2 -month bill is just the innovation in the 1-month nominal interest rate). The 20 -year bond might also be a plausible benchmark, since the unexpected component of its return contains a discounted sum of innovations in expected future nominal interest rates (Campbe11 [1984a]). If any of these individual assets is indeed the economy's benchmark portfolio, then the variables which predict movements in its excess return should predict proportional movements in its conditional variance. ${ }^{15}$

In Table 4 I present GMM estimates of a system like (3.1), for each of the three assets and two sample periods of the paper. The vector $\mathrm{x}_{j \mathrm{t}}$ provides $\mathrm{J}$ instruments, so $2 \mathrm{~J}$ orthogonality conditions can be used in estimation. The system is slightly modified from (3.1), in that it includes a constant term in the equation describing the vari-

15 Merton [1980] argues that the expected return on the stock market can be estimated more precisely from the variance of the return than from sample average returns. However he does not consider conditional expected returns and does not directly test the hypothesis of proportionality across the first and second moments of returns. Engle, Lilien and Robins [1985] adopt an approach which is closer to that taken here, but specify that returns follow an ARCH process rather than having moments which are exact linear functions of information variables. They apply their model to the term structure and find as here that there is a positive relationship between bill returns and their conditional variance. 
ance. ${ }^{16}$ If (3.1) holds, then the constant should be zero. Estimates of $J+2$ coefficients - $\alpha_{j}, f$ and the constant - are presented with standard errors. Probability values are reported for Chi-square tests of the cross-equation restrictions imposed by the estimated system, and of the hypothesis that $\alpha_{j}$ are zero except for a constant (below, in parentheses).

The results in Table 4 are quite mixed. The constant term in the variance equation is always significantly different from zero, except in row 4 (bill returns 1959-83). This may reflect the fact that the coefficients in Tables 1 were large enough to predict negative excess returns in some periods; if this is not to imply negative conditional variances in Table 4, there must be a constant in the variance equation. In any event, significant constants suffice to reject (3.1) against the more general alternative estimated.

On the other hand, the coefficient $f$ is also significantly different from zero in rows 3,4 and 6 (bill returns $1959-83$ and stock returns in both sample periods). This indicates that there is some common movement in conditional first and second moments of returns. Curiously, the estimated $f$ coefficient for stocks is negative, suggesting that stocks have a higher expected return when their conditional variance is low. ${ }^{17}$

16 Non-negativity of the variance is not imposed in estimation. The errors $u$ and $v$ have a deterministic nonlinear relationship given the parameters, and $\mathrm{v}$ must be highly nonnormal, but error-instrument orthogonality can still be used to estimate and test the system.

17 This is perhaps not as surprising as it seems at first. Experiment with a separate coefficient for the 1 -month bill rate in the stock variance equation confirmed that the conditional variance of stock returns is low when the bill rate is low; but at such a time stocks 
Further evidence of dynamic behavior of the conditional variance comes from the test statistics for the estimated system. If this system is rejected (as it is for bills, and bonds 1959-78), then this is evidence of correlation of the conditional variance with information variables, which does not obey the proportionality restriction.

Table 4 uses only the behavior of own returns, in evaluating the hypothesis that a particular asset is the economy's benchmark portfo1io. An alternative approach is to test the restrictions imposed by that hypothesis on other assets' returns. As shown in more detail in Appendix A, a further implication of the ICAPM is that for each excess return eh ${ }_{i t}$, the following holds:

$$
\text { (3.2) } \text { eh }_{i t}=\beta_{i z t} e_{z t}+u_{i t}
$$

where eh ${ }_{i t}$ is the excess return on the $i^{\prime}$ th asset over the riskfree rate, $\beta_{i z t}=\operatorname{Cov}_{t}\left(e h_{i t}\right.$, eh $\left.z t\right) / \operatorname{Var}_{t}\left(e h_{z t}\right)$, and $u_{i t}$ is an unexpected return which is orthogonal not only to the benchmark portfolio return but to any variables which are known at $t$. The assumption that betas are exact linear functions of information variables means that we can write $\beta_{i z t}=\delta_{i 1} x_{1 t}+\ldots+\delta_{i J} x_{J t}$. Substituting this expression into equation (3.2), we obtain

(3.3) eh ${ }_{i t}=\left[\sum_{j=1}^{J} \delta_{i j} x_{j t}\right]$ eh ${ }_{z t}+u_{i t}$

have high expected returns. 
Since eh ${ }_{z t}$ is assumed to be observable, (3.3) can be estimated as a regression of $\mathrm{eh}_{i t}$ on the cross-products of information variables $x_{j t}$ and the excess return eh ${ }_{z t}$. If the model is correctly specified, the error term $\mathfrak{u}_{i t}$ is orthogonal not only to these cross-products, but to all elements of the market's information set; in particular, it is orthogonal to the vector $\mathrm{x}_{\mathrm{jt}}$. This implication of the model can be tested by running a regression of $\mathrm{eh}_{i t}$ on the set of cross-products of information variables with $\mathrm{eh}_{\mathrm{zt}}$, and on the information variables included separately:

(3.4) eh $i t=\left[\sum_{j=1}^{J} \delta_{i j} x_{j t}\right]$ eh $z t+\sum_{j=1}^{J} \gamma_{i j} x_{j t}+u_{i t}$

If the coefficients $\gamma_{i j}$ on the information variables are jointly significant, the model is rejected. Such a test can be conducted for a single asset, or for several assets in a system of regression equations. ${ }^{18}$

The coefficients on the cross-products can be interpreted independently of the asset pricing model test methodology. A significant coefficient on the cross-product of the $j^{\prime}$ th information variable and $\mathrm{eh}_{z t}$ indicates a significant correlation between the information variable $x_{j t}$ and the cross-product of eh ${ }_{i t}$ with $e_{z t}$. The existence of such a correlation is of interest whatever the outcome of a particular asset pricing model test.

18 This test may be interpreted as an extension to a particular dynamic setting of Gibbons' [1982] multivariate approach to testing the static CAPM. 
There are several possible reasons for a rejection of the restrictions in (3.3). The benchmark portfolio or the riskfree rate may be misspecified or measured with error. Alternatively, the specification of the betas may be incorrect. To see how this could lead to a rejection of the model, consider the case where the benchmark portfolio and riskfree returns are correctly measured. However the beta of asset $i$ is modelled as $\beta_{i z t}=\delta_{i 0}+\delta_{i 1} x_{1 t}$ when in fact it is $\beta_{i z t}=$ $\delta_{i 0}+\delta_{i 1} x_{1 t}+\delta_{i 2} x_{2 t}$, where $x_{2 t}=\checkmark x_{1 t}$. Equation (3.4) will now have an error $\delta_{i 2} x_{2 t} e_{z t}+u_{i t}$. In general eh ${ }_{z t}$ will be a function of the information variables; thus the equation error contains a term in the square of $x_{2 t}$, that is a term in $x_{1 t}$. This will cause $\gamma_{i 1}$ to be estimated nonzero, and the proposed test will reject the model.

I now apply this test to the data on bill, bond and stock returns. Since the analysis is exploratory, I maintain a single-equation regression approach, testing (3.3) on one asset at a time.

In Table 5, each asset in turn is regressed on the cross-products of information variables with each other asset, and on the information variables included separately. As before, all the information variables which appear in Tables 1 are included in the test. Heteroskedasticity-consistent significance levels, derived from White's covariance matrix estimator, are reported for the cross-products and for the information variables included separately. Separate test statistics are reported for the coefficients including and excluding the constant term. Thus the first column of significance levels in Table 5 is for the hypothesis that the coefficients in equation (3.4) on cross-products of all information variables, including the constant, with eh 
are zero: $\delta_{i j k}=0, j=1 \ldots J, k=1$. The second column is for the hypothesis that the coefficients on all cross-products except that of the constant with the hedge portfolio return are zero: $\delta_{i j k}=0$, $j=2 \ldots J, k=1$. The third column is for the hypothesis that all information variables, included separately, have zero coefficients: $\gamma_{i j}=$ $0, j=1 \ldots J$. The fourth column is for the hypothesis that all except the constant have zero coefficients: $\gamma_{i j}=0, j=2 \ldots J$. We may interpret the second column as testing whether changes in the covariance matrix of asset returns are associated with movements in information variables, the third column as testing the full set of restrictions (3.3), and the fourth column as testing whether movements in asset returns (ignoring average levels) are explained by the model (3.3).

The first six rows of Table 5 are for the short sample period 1959-78, and the last six rows are for the $1959-83$ period. The significance levels of information variables, when these are included in a regression without cross-products (as in Tables 1) are reported in brackets underneath each element of columns 3 and 4.

Summarizing the results of the table, there is little evidence that movements in information variables are associated with changes in covariances of asset returns, except for the covariance of bond and stock returns (rows 4, 6, 10 and 12). The specification (3.3) with bonds as the dependent variable and stocks as the hedge portfolio is not rejected for either sample period (rows 4 and 10); however for the long sample period the information variables do not explain bond returns even when cross-products are excluded (row 10). The stock hedge portfolio model does not explain bill returns in either sample period. 
These results are discouraging for the simple models described in the introduction to the paper. However I now test a slightly more general specification, and obtain more encouraging results. I now assume that some fixed-weight combination of observable asset returns is perfectly correlated with the benchmark portfolio:

$\mathrm{eh}_{z t}=\sum_{i=1}^{\mathrm{I}} \mathrm{w}_{i}$ eh $\mathrm{ht}_{\mathrm{t}}$

The weights $w_{i}$ are parameters which must be estimated. The equation system (3.3) now becomes

(3.5) eh it $=\left\{\left[\sum_{j=1}^{J} \delta_{i j} x_{j t}\right]\left[\sum_{i=1}^{I} w_{i} e_{i t}\right]\right\}+u_{i t} \quad i=1 \ldots I$

To identify the system, I normalize $\sum \omega_{i}=1$. The restriction relating the conditional mean and variance of $\mathrm{eh}_{z t}$, which was stated in equation (3.1), can also be tested in conjunction with (3.5) as part of an (I+2)-equation system. The errors $u_{i t}$ are orthogonal to the information variables $x_{j t}, j=1 \ldots J$, and their cross-products with the benchmark portfolio return. Thus there are $2 \mathrm{IJ}$ orthogonality conditions from these equations. The errors $u_{z t}$ and $v_{z t}$ are orthogonal to the $x_{j t}$ and contribute $2 J$ more orthogonality conditions for a total of $2(I+1) J$. There are $I J \delta_{i j}$ parameters, I-1 $w_{i}$ parameters, $J \alpha_{j}$ parameters, and a proportionality parameter $f$, along with a constant if this is included in the benchmark portfolio variance equation. Thus there are $(\mathrm{I}+1)(\mathrm{J}+1)-1$ or $(\mathrm{I}+1)(\mathrm{J}+1)$ parameters to be estimated. The system 
is identified for any positive $J$, with overidentifying restrictions whose number grows with $\mathrm{J}$.

In Table 6 I present GMM estimates and test statistics for a combined system of equations (3.1) and (3.5) with a fixed-weight estimated portfolio. In the 1959-78 sample period, the estimated portfolio places unit weight (to 3 significant digits) on 2-month bills; it is short on 20-year bonds and long on stocks, with $0.3 \%$ weight on each of these assets. Despite the very low portfolio shares of the long-term assets, the variance of their returns is sufficiently high relative to the variance of bill returns that they contribute $2 \%$ and $8 \%$ respectively of the total variance of the portfolio return.

Within the framework of the model, one cannot reject the hypothesis that the conditional variance of the excess return eh ${ }_{z t}$ is proportional to its conditional mean. The constant term in the variance equation is estimated at less than one tenth of its standard error, while the proportional term has the plausible value of 0.448 . Thus the model estimates $\mathrm{eh}_{\mathrm{zt}}=-2.23 \mathrm{eh}_{\mathrm{bt}}$.

The excess return eh ${ }_{z t}$ moves in a similar manner to the 2-month bill excess return; in particular, it is high when the 2 -month spread is high. However it is also high when the lagged excess return on 2-month bills is high, reflecting the stock component of the portfo1io. Movements in the excess return on 2 -month bills are partly attributed to movements in the beta of the 2-month bill with eh $\mathrm{zt}_{\text {; }}$ this is low when the lagged excess return on 2 -month bills is high, offsetting the positive effect of the lagged excess return on eh ${ }_{z t}$. There are also significant movements in the betas of the other assets with 
the benchmark portfolio. Although the estimates and standard errors appear sensible, the Chi-square test of the model's cross-equation restrictions rejects the model at the $0.4 \%$ level.

In the 1959-83 period, the results are qualitatively similar. Once again the portfolio with excess return eh ${ }_{z t}$ is estimated to consist almost entirely of 2 -month bills. It is short $0.8 \%$ bonds, and long $0.1 \%$ stocks; bonds and stocks account for $14 \%$ and 1 ess than $1 \%$ respectively of the variance of the portfolio return. The conditional first and second moments of $\mathrm{eh}_{z t}$ are again close to proportional, and there are significant movements in all assets' betas with the benchmark. The Chi-square test of the model now fails to reject at the $40 \%$ leve1.

The results of Tables 4-6, taken together, suggest that there is some truth to the idea that movements in uncertainty about nominal interest rates explain movements in expected asset returns. The excess return on 2 -month bills over 1 -month bills does tend to be high when its conditional variance is high, and in the 1959-83 period one cannot reject the hypothesis that the relationship is proportional. Although a direct regression test shows that predictable stock and bond returns are not entirely explained by time varying betas with a 2-month bill portfolio, the system estimated in Table 6 chooses a benchmark portfo1 io in which 2-month bills dominate. For the 1959-83 period, that system is not rejected by a Chi-square test, and in both periods the conditional first and second moments of the estimated excess return $\mathrm{eh}_{z t}$ move in proportion. 


\section{Conclusion}

In this paper I have documented that the expectations theories for bills, bonds and stocks can be rejected at high levels of confidence. When realized excess returns on these assets are regressed on information variables which measure the state of the term structure, the fitted values are far from constant. Instead, they vary with a standard deviation for the 1959-1978 period of almost $1 / 4 \%$ per month on an annualized basis for bills, $6 \%$ for bonds and $17 \%$ for stocks. Over the same period average bond returns were $11 / 2 \%$ a year less than bill returns and 5\% less than stock returns.

These observations can be used to test simple asset pricing models, and to guide the formulation of more elaborate models. In this paper I have confined my attention to models which can be tested using only data on asset returns and information variables. I show in section 2 that the data strongly reject models in which betas are constant and risk premia are driven by time variation in a single latent variable. There is weak evidence against even a more general two-latent-variable model in the 1959-1978 period.

In section 3 I test models in which one of the assets studied, or some fixed linear combination of them, has an excess return over the riskfree rate which is perfectly conditionally correlated with the marginal utility of consumption. The conditional first and second moments of such an excess return move approximately in proportion, and predictability of excess returns on other assets can be explained by their covariance with this return. Popular explanations of risk premia which stress output or interest rate uncertainty can be interpret- 
ed as saying that returns on stock or 2-month bills have these properties. The traditional 1-period CAPM in which the market portfolio is taken to be the stock market also makes this claim for stocks.

I find that expected stock returns have a negative relationship with the conditional variance of stock returns, but that 2 -month bill returns move positively with their conditional variance. When I estimate a system which allows free but fixed weights on bills, bonds and stocks in the benchmark portfolio, it places almost all the weight on 2-month bills and does not reject the restriction that the first and second conditional moments of the benchmark return move in proportion. The coefficient estimates in the fixed-weight model are plausible, although the system is rejected at the $1 / 2 \%$ level for the $1959-78$ period.

In summary, it appears that time variation in the conditional covariance matrix of bill, bond and stock returns is an important part of the explanation for time-varying risk premia on these assets. The results of the paper suggest that uncertainty about short-term nominal interest rates, as measured by the conditional variance of 2 -month bill returns, is important in pricing both Treasury bills and longterm assets. Uncertainty about stock returns, by contrast, seems to have a negative relationship with expected stock returns and does not help to explain returns in the term structure.

Clearly it would be desirable to relate the time-varying expected returns documented in this paper to developments in the real economy. The preliminary exploration of asset return data in this paper is a prelude to an account of the macroeconomic sources of time-varying risk premia. 


\section{Appendix A: Relation of Empirical Asset Pricing Models}

\section{to the Intertemporal CAPM}

In this Appendix I relate the models of sections 2 and 3 to the intertemporal CAPM of Merton [1973], Breeden [1979], Hansen, Richard and Singleton [1981] and others. Formulated in discrete time with a representative agent with time-separable utility u defined over consumption $c$, this model implies that for any asset $i$, the one-period return from time $t$ to time $t+1, h_{i t}$, must satisfy the first-order condition

(A.1) $\quad E_{t}\left[d\left(u^{\prime}\left(c_{t+1}\right) / u^{\prime}\left(c_{t}\right)\right)\left(1+h_{i t}\right)\right]=1$

Here $E_{t}$ denotes expectation conditional on the full information set of the representative agent at time $t, d$ is a discount factor.

(A.1) is testable directly if consumption is observable and the form of the utility function is known. Hansen and Singleton [1982] have developed econometric techniques for testing (A.1), and Campbe11 [1984a] applies them to the data of this paper assuming constant relative risk aversion utility.

An indirect approach to testing the model is as follows. Define $m_{t, t+1}$ to be the discounted ratio of the marginal utility of consumption at time $t+1$ to the marginal utility at time $t, d \cdot u^{\prime}\left(c_{t+1}\right) / u^{\prime}\left(c_{t}\right)$. Then (A.1) can be rewritten as

$$
E_{t}\left[m_{t, t+1}\left(1+h_{i t}\right)\right]=1 \quad \text { for all assets } i
$$


where as before $E_{t}$ denotes the expectation conditional on the full information set of the market.

Now consider the portfolio b with return

$\left(1+h_{b t}\right)=m_{t, t+1} / E_{t}\left[m_{t, t+1}^{2}\right]$

Hansen, Richard and Singleton [1981] call this portfolio the "benchmark portfolio". Its return is perfectly correlated with $m_{t, t+1}$, conditional on information available at time $t$. It is trivial to show that

(A.2) $\quad E_{t}\left[\left(1+h_{b t}\right)\left(1+h_{i t}\right)\right]=1 / E_{t}\left[m_{t, t+1}^{2}\right]$

for all assets or portfolios $i$, including $i=b$.

Now consider the riskfree rate of return

$\left(1+h_{0 t}\right)=1 / E_{t} m_{t, t+1}$

From (A.2),

$E_{t}\left[\left(1+h_{b t}\right)\left(1+h_{i t}\right)\right]=\left(1+h_{0 t}\right) E_{t}\left(1+h_{b t}\right)$

and expanding the mean of the product into the sum of the covariance and the product of the means,

(A.3) $E_{t} h_{i t}-h_{0 t}=-\operatorname{Cov}_{t}\left[h_{i t}, h_{b t}\right] / E_{t}\left(1+h_{b t}\right)$

Since this holds for all $i$, including $i=b$, we have 
(A.4) $E_{t} h_{b t}-h_{0 t}=-\operatorname{Var}_{t} h_{b t} / E_{t}\left(1+h_{b t}\right)$

Solving for $E_{t}\left(1+h_{b t}\right)$ and substituting into (A.3), we obtain

(A.5) $E_{t} h_{i t}-h_{0 t}=\beta_{i t}\left[E_{t} h_{b t}-h_{0 t}\right]$

where $\beta_{i t}=\operatorname{Cov}_{t}\left[h_{i t}, h_{b t}\right] / \operatorname{Var}_{t}\left[h_{b t}\right]$.

Equation (A.5) is a linear relationship, holding at any point in time, between the conditional expected return on any asset $i$ and the conditional expected return on the benchmark portfolio. Unfortunate$l y$, in general $h_{b t}$ is unobservable and $\beta_{i t}$, the slope of this relationship, varies through time. However under additional assumptions (A.5) may be testable. I now discuss the assumptions necessary to generate a) the models of section 2 , and b) the models of section 3 , from equations (A.4) and (A.5). These assumptions are arbitrary and not derived from underlying assumptions about tastes and technology.

a) Assume (i) the benchmark portfolio is a time-varying weighted combination of the riskless asset with return $h_{0 t}$ and $k$ risky portfolios indexed by $k=1 \ldots K$ with orthogonal returns $h_{1 t}, \ldots, h_{K t}: h_{b t}=$ $w_{0 t} h_{0 t}+w_{1 t} h_{1 t}+\ldots+w_{K t} h_{K t}$, where $w_{0 t}$, $w_{1 t}, \ldots, w_{K t}$ are scalars summing to unity. Further assume (ii) that individual assets have constant conditional betas with the portfolios $k=1 \ldots K$. This would follow from but is weaker than the assumption of Gibbons and Ferson [1983] that the conditional covariance matrix of asset returns is constant; Gibbons and Ferson's assumption is unappealing in a setting in 
which expected asset returns are moving through time. For example, in the 1-period CAPM changing expected returns and constant betas can be obtained simply by allowing the variances and covariances of all asset returns to move in proportion. This is allowed by assumption (ii) but not by Gibbons and Ferson's assumption.

Then

(A.6) $\quad \beta_{i t}=\sum_{k=1}^{K} w_{k t}\left(\operatorname{Var}\left(h_{k t}\right) / \operatorname{Var}_{t}\left(h_{b t}\right)\right) \beta_{i k}$

where $B_{i k}$ is the constant beta of asset $i$ with portfolio $k$.

Since (A.6) holds for all assets and portfolios, including portfolio $k$, and this portfolio by construction has a zero beta with all other portfolio returns $h_{1}, \ldots, h_{k-1}, h_{k+1}, \ldots, h_{K}$, we have $w_{k t}\left(\operatorname{Var}\left(h_{k t}\right) / \operatorname{Var}_{t}\left(h_{b t}\right)\right)\left[E_{t} h_{b t}-h_{0 t}\right]=E_{t} h_{k t}-h_{0 t}$, and

(A. 7) $E_{t} h_{i t}-h_{0 t}=\sum_{k=1}^{K} \beta_{i k}\left[E_{t} h_{k t}-h_{0 t}\right]$

(A.7) for equation $j$ can be subtracted from (A.7) for equation $i$, so it is not essential to be able to measure the risk-free rate if the $\left[E_{t} h_{k t}-h_{0 t}\right]$ are already taken to be unobservable. Then equations (A.7) are just the K-factor model of section 2 .

b) Drop (ii) above, but assume that some excess return $h_{z t}-h_{0 t}$, perfectly correlated with $h_{b t}-h_{0 t}$, is observable. (This is a weaker assumption than assuming that $h_{z t}$ itself is observable, since it allows one to measure returns in nominal rather than real terms.) We can write $h_{z t}-h_{0 t}=(-1 / f)\left(h_{b t}-h_{0 t}\right)$ for some positive or negative $f$. 
Then (A.4) states that $E_{t} h_{z t}-h_{0 t}=f \operatorname{Var}_{t} h_{b t} / E_{t}\left(1+h_{b t}\right)$. This relationship is the foundation of the assertion in section 3 of the text that first and second conditional moments of the benchmark return are approximately proportional. The approximation arises from the fact that the conditional variance is divided by $E_{t}\left(1+h_{b t}\right)$. However $E_{t} h_{b t}$ is always very small relative to one; it shrinks as the unit time interval shrinks, so in the continuous limit the proportionality relationship is exact. For the monthly data of this paper, the standard deviation of $E_{t} h_{b t}$ is unlikely to be higher than the standard deviation of the ex ante returns reported in Table 2. For example, the 2-standard deviation band for excess stock returns in $1959-78$ is $34 \%$ on an annual basis, or from -0.025 to 0.028 in natural units on a monthly basis. Thus the approximation involved in testing the proportionality restriction in section 3 should be small.

The cross-asset restrictions of section 3 follow directly from equation (A.5). Section 3 equates eh ${ }_{i t}$ with $h_{i t}{ }^{-h}{ }_{0 t}$, so it relies on the assumption that the real return on 1 -month Treasury bills is riskless. 
Appendix B: Data Sources and Transformations

Data were obtained and transformed as follows:

1) Until November 1982, discount rates on Treasury bills were quoted in the U.S. Treasury Bulletin, for a trading date at the end of the previous month. The source for these rates was the first issue of the Wall Street Journal for each month, and this original source was used for the November 1982-November 1983 period. The rates were converted from discount basis to bond-equivalent yield basis using the formula $\mathrm{r}=\mathrm{D} /(1-\mathrm{D} / 100 \mathrm{n})$, where $\mathrm{n}=12 / \mathrm{m}, \mathrm{m}=$ maturity of bill in months.

The 1-month holding return on a 2 -month Treasury bill was computed as $2 R_{2 t}-R_{1, t+1}$, which is a linear approximation analogous to the one employed for long bond yields.

2) Salomon Brothers' Analytical Record of Yields and Yield Spreads [1983] gives point sampled bond yields monthly from 1950:1 to the present. Rates are quoted at the beginning of each month from 1959: 1 onwards.

Monthly holding returns on long bonds were calculated using the linearized approximate formula of Shiller, Campbell and Schoenholtz [1983]. The point of linearization was the average 20-year bond rate in the period $1959: 1$ to $1978: 9,0.058712$ or 0.00489 on a monthly basis.

The formula expresses the monthly holding return on a long bond as a linear function of the yield on the bond at the beginning and end of the month. The formula is $h_{i t}=D_{i} R_{i t}-\left(D_{i}-1\right) R_{i-1, t+1}$, where $h_{i t}$ 
is the 1 -month holding return at time $t$ on an $i$-period bond, $R_{i t}$ is the yield at time $t$ on an i-period bond, and $D_{i}$ is the "duration" of an $i$-period bond. $D_{i}$ is calculated as $(1-\theta * i) /(1-\theta)$, where $\theta=$ $1 /(1+Y)$, and $Y=0.00489$ as above. $D_{240}=141.73$ months, or just under 12 years.

Campbe11 [1984c] investigates the accuracy in practice of the linear approximations used in this paper.

3) Stock returns are measured by the value-weighted return on the New York Stock Exchange, including dividend return, obtained from the CRSP data tape (Center for Research in Securities Prices, Graduate School of Business, University of Chicago).

4) OLS regressions and standard error corrections were performed using the mainframe software package PEC (Program for Econometric Computation); GMM estimation was carried out on an IBM PC/XT using the software package GAUSS. The objective function was minimized by a Gauss-Newton algorithm with modified step size, operating on analytic formulae for derivatives. 
TABLE 1A

Excess Bill Returns

\begin{tabular}{|c|c|c|c|c|c|c|c|}
\hline Row & Constant & $\begin{array}{l}\text { 1-Month } \\
\text { Rate }\end{array}$ & $\begin{array}{l}\text { 2-Month } \\
\text { Spread }\end{array}$ & $\begin{array}{l}20 \text {-Year } \\
\text { Spread }\end{array}$ & $\begin{array}{l}\text { Lagged } \\
\text { Excess } \\
2 \text {-Month } \\
\text { Return }\end{array}$ & $\begin{array}{l}\text { R-Squared } \\
\text { (DW) }\end{array}$ & $\begin{array}{c}\text { Max Hat } \\
\text { (P-Value) }\end{array}$ \\
\hline 1 & $\begin{array}{c}0.338 \\
(0.117) \\
(0.120)\end{array}$ & $\begin{array}{l}-0.023 \\
(0.028) \\
(0.029)\end{array}$ & --- & --- & --- & $\begin{array}{c}0.006 \\
(1.707)\end{array}$ & $\begin{array}{r}0.039 \\
(43.3 \%) \\
(44.5 \%)\end{array}$ \\
\hline 2 & $\begin{array}{c}0.004 \\
(0.108) \\
(0.111)\end{array}$ & $\begin{array}{c}0.012 \\
(0.027) \\
(0.027)\end{array}$ & $\begin{array}{c}1.351 \\
(0.141) \\
(0.145)\end{array}$ & --- & --- & $\begin{array}{c}0.216 \\
(2.064)\end{array}$ & $\begin{array}{c}0.136 \\
(<0.05 \%) \\
(<0.05 \%)\end{array}$ \\
\hline 3 & $\begin{array}{c}0.373 \\
(0.113) \\
(0.115)\end{array}$ & $\begin{array}{l}-0.027 \\
(0.026) \\
(0.027)\end{array}$ & $-\cdots$ & $\begin{array}{l}-0.015 \\
(0.030) \\
(0.031)\end{array}$ & --- & $\begin{array}{c}0.007 \\
(1.697)\end{array}$ & $\begin{array}{r}0.042 \\
(51.3 \%) \\
(52.6 \%)\end{array}$ \\
\hline 4 & $\begin{array}{c}0.248 \\
(0.109) \\
(0.114)\end{array}$ & $\begin{array}{l}-0.011 \\
(0.027) \\
(0.028)\end{array}$ & --- & ---- & $\begin{array}{c}0.154 \\
(0.114) \\
(0.124)\end{array}$ & $\begin{array}{c}0.028 \\
(2.029)\end{array}$ & $\begin{array}{r}0.146 \\
(39.1 \%) \\
(45.4 \%)\end{array}$ \\
\hline 5 & $\begin{array}{c}0.081 \\
(0.100) \\
(0.105)\end{array}$ & $\begin{array}{c}0.004 \\
(0.024) \\
(0.025)\end{array}$ & $\begin{array}{c}1.340 \\
(0.140) \\
(0.146)\end{array}$ & $\begin{array}{l}-0.047 \\
(0.026) \\
(0.026)\end{array}$ & $\begin{array}{c}0.065 \\
(0.105) \\
(0.115)\end{array}$ & $\begin{array}{c}0.227 \\
(2.144)\end{array}$ & $\begin{array}{c}0.151 \\
(<0.05 \%) \\
(<0.05 \%)\end{array}$ \\
\hline 6 & $\begin{array}{l}-0.133 \\
(0.130) \\
(0.134)\end{array}$ & $\begin{array}{c}0.088 \\
(0.028) \\
(0.028)\end{array}$ & --- & --- & -- & $\begin{array}{c}0.098 \\
(1.284)\end{array}$ & $\begin{array}{r}0.042 \\
(0.2 \%) \\
(0.2 \%)\end{array}$ \\
\hline 7 & $\begin{array}{l}-0.183 \\
(0.131) \\
(0.136)\end{array}$ & $\begin{array}{c}0.057 \\
(0.028) \\
(0.029)\end{array}$ & $\begin{array}{c}1.159 \\
(0.237) \\
(0.248)\end{array}$ & $\cdots$ & --- & $\begin{array}{c}0.254 \\
(1.673)\end{array}$ & $\begin{array}{c}0.151 \\
(<0.05 \%) \\
(<0.05 \%)\end{array}$ \\
\hline 8 & $\begin{array}{l}-0.270 \\
(0.148) \\
(0.152)\end{array}$ & $\begin{array}{c}0.098 \\
(0.027) \\
(0.028)\end{array}$ & $-\cdots$ & $\begin{array}{c}0.068 \\
(0.058) \\
(0.060)\end{array}$ & $-\cdots$ & $\begin{array}{c}0.108 \\
(1.341)\end{array}$ & $\begin{array}{c}0.063 \\
(0.1 \%) \\
(0.2 \%)\end{array}$ \\
\hline 9 & $\begin{array}{c}-0.194 \\
(0.133) \\
(0.138)\end{array}$ & $\begin{array}{c}0.076 \\
(0.029) \\
(0.030)\end{array}$ & --- & $-\cdots$ & $\begin{array}{c}0.348 \\
(0.096) \\
(0.106)\end{array}$ & $\begin{array}{c}0.217 \\
(1.962)\end{array}$ & $\begin{array}{c}0.175 \\
(<0.05 \%) \\
(<0.05 \%)\end{array}$ \\
\hline 10 & $\begin{array}{l}-0.083 \\
(0.125) \\
(0.131)\end{array}$ & $\begin{array}{c}0.045 \\
(0.026) \\
(0.027)\end{array}$ & $\begin{array}{c}0.929 \\
(0.226) \\
(0.241)\end{array}$ & $\begin{array}{l}-0.066 \\
(0.049) \\
(0.052)\end{array}$ & $\begin{array}{c}0.239 \\
(0.102) \\
(0.114)\end{array}$ & $\begin{array}{c}0.296 \\
(1.954)\end{array}$ & $\begin{array}{c}0.195 \\
(<0.05 \%) \\
(<0.05 \%)\end{array}$ \\
\hline
\end{tabular}

Sample period: rows 1 to $5,1959: 2-1978: 9$, rows 6 to $10,1959: 2-1983: 11$. 
TABLE $1 \mathrm{~B}$

Excess Bond Returns

\begin{tabular}{|c|c|c|c|c|c|c|c|}
\hline Row & Constant & $\begin{array}{l}\text { 1-Month } \\
\text { Rate }\end{array}$ & $\begin{array}{l}2 \text {-Month } \\
\text { Spread }\end{array}$ & $\begin{array}{l}20 \text {-Year } \\
\text { Spread }\end{array}$ & $\begin{array}{l}\text { Lagged } \\
\text { Excess } \\
2 \text {-Month } \\
\text { Return }\end{array}$ & $\begin{array}{l}\text { R-Squared } \\
\text { (DW) }\end{array}$ & $\begin{array}{l}\text { Max Hat } \\
\text { (P-Value }\end{array}$ \\
\hline 1 & $\begin{array}{c}2.980 \\
(3.996) \\
(4.055)\end{array}$ & $\begin{array}{l}-0.999 \\
(1.010) \\
(1.026)\end{array}$ & --- & --- & ---- & $\begin{array}{c}0.004 \\
(2.019)\end{array}$ & $\begin{array}{r}0.039 \\
(32.5 \%) \\
(33.3 \%)\end{array}$ \\
\hline 2 & $\begin{array}{l}-1.875 \\
(4.631) \\
(4.749)\end{array}$ & $\begin{array}{l}-0.494 \\
(1.043) \\
(1.064)\end{array}$ & $\begin{array}{c}19.659 \\
(10.634) \\
(11.517)\end{array}$ & --- & -- & $\begin{array}{c}0.020 \\
(2.034)\end{array}$ & $\begin{array}{r}0.136 \\
(10.5 \%) \\
(14.3 \%)\end{array}$ \\
\hline 3 & $\begin{array}{l}-6.080 \\
(4.925) \\
(4.996)\end{array}$ & $\begin{array}{c}0.015 \\
(1.012) \\
(1.030)\end{array}$ & ---- & $\begin{array}{c}3.832 \\
(1.850) \\
(1.882)\end{array}$ & ---- & $\begin{array}{c}0.024 \\
(2.025)\end{array}$ & $\begin{array}{r}0.042 \\
(10.3 \%) \\
(11.2 \%)\end{array}$ \\
\hline 4 & $\begin{array}{l}-2.587 \\
(4.373) \\
(4.536)\end{array}$ & $\begin{array}{l}-0.281 \\
(1.033) \\
(1.066)\end{array}$ & ---- & ---- & $\begin{array}{c}9.559 \\
(3.952) \\
(4.188)\end{array}$ & $\begin{array}{c}0.034 \\
(2.128)\end{array}$ & $\begin{array}{r}0.146 \\
(3.8 \%) \\
(5.3 \%)\end{array}$ \\
\hline 5 & $\begin{array}{r}-11.585 \\
(5.352) \\
(5.525)\end{array}$ & $\begin{array}{c}0.681 \\
(1.039) \\
(1.077)\end{array}$ & $\begin{array}{c}12.997 \\
(10.382) \\
(11.320)\end{array}$ & $\begin{array}{c}2.941 \\
(1.851) \\
(1.899)\end{array}$ & $\begin{array}{c}7.558 \\
(4.033) \\
(4.322)\end{array}$ & $\begin{array}{c}0.053 \\
(2.111)\end{array}$ & $\begin{array}{r}0.151 \\
(3.5 \%) \\
(5.3 \%)\end{array}$ \\
\hline
\end{tabular}

\begin{tabular}{|c|c|c|c|c|c|c|c|}
\hline 6 & $\begin{array}{c}2.017 \\
(6.854) \\
(7.031)\end{array}$ & $\begin{array}{l}-0.776 \\
(1.459) \\
(1.497)\end{array}$ & ---- & ---- & ---- & $\begin{array}{c}0.003 \\
(1.775)\end{array}$ & $\begin{array}{r}0.042 \\
(60.2 \%) \\
(61.1 \%)\end{array}$ \\
\hline 7 & $\begin{array}{c}1.769 \\
(6.904) \\
(7.157)\end{array}$ & $\begin{array}{l}-0.933 \\
(1.489) \\
(1.540)\end{array}$ & $\begin{array}{c}5.818 \\
(17.171) \\
(18.935)\end{array}$ & $\cdots$ & --- & $\begin{array}{c}0.004 \\
(1.770)\end{array}$ & $\begin{array}{r}0.151 \\
(80.6 \%) \\
(82.0 \%)\end{array}$ \\
\hline 8 & $\begin{array}{r}-11.301 \\
(7.990) \\
(8.227)\end{array}$ & $\begin{array}{c}0.200 \\
(1.446) \\
(1.493)\end{array}$ & --- & $\begin{array}{c}6.677 \\
(3.173) \\
(3.292)\end{array}$ & ---- & $\begin{array}{c}0.038 \\
(1.832)\end{array}$ & $\begin{array}{r}0.063 \\
(10.8 \%) \\
(12.6 \%)\end{array}$ \\
\hline 9 & $\begin{array}{c}1.037 \\
(7.066) \\
(7.323)\end{array}$ & $\begin{array}{c}-0.972 \\
(1.470) \\
(1.522)\end{array}$ & ---- & $\cdots$ & $\begin{array}{c}5.597 \\
(5.516) \\
(5.863)\end{array}$ & $\begin{array}{c}0.015 \\
(1.871)\end{array}$ & $\begin{array}{r}0.175 \\
(48.7 \%) \\
(52.4 \%)\end{array}$ \\
\hline 10 & $\begin{array}{r}-10.942 \\
(7.389) \\
(7.784)\end{array}$ & $\begin{array}{c}0.235 \\
(1.444) \\
(1.524)\end{array}$ & $\begin{array}{c}-6.871 \\
(18.048) \\
(20.230)\end{array}$ & $\begin{array}{c}6.376 \\
(2.964) \\
(3.149)\end{array}$ & $\begin{array}{c}3.040 \\
(5.750) \\
(6.282)\end{array}$ & $\begin{array}{c}0.041 \\
(1.891)\end{array}$ & $\begin{array}{r}0.195 \\
(29.7 \%) \\
(35.7 \%)\end{array}$ \\
\hline
\end{tabular}

Sample period: rows 1 to $5,1959: 2-1978: 9$, rows 6 to $10,1959: 2-1983: 11$. 
TABLE $1 \mathrm{C}$

Excess Stock Returns

\begin{tabular}{|c|c|c|c|c|c|c|c|}
\hline Row & Constant & $\begin{array}{l}\text { 1-Month } \\
\text { Rate }\end{array}$ & $\begin{array}{l}\text { 2-Month } \\
\text { Spread }\end{array}$ & $\begin{array}{l}20-Y e a r \\
\text { Spread }\end{array}$ & $\begin{array}{l}\text { Lagged } \\
\text { Excess } \\
2 \text {-Month } \\
\text { Return }\end{array}$ & $\begin{array}{l}\text { R-Squared } \\
\text { (DW) }\end{array}$ & $\begin{array}{c}\text { P-Value } \\
\text { (Max Hat) }\end{array}$ \\
\hline 1 & $\begin{array}{l}29.423 \\
(9.428) \\
(9.569)\end{array}$ & $\begin{array}{l}-5.682 \\
(2.199) \\
(2.234)\end{array}$ & $-\cdots$ & --- & $\cdots$ & $\begin{array}{c}0.038 \\
(1.907)\end{array}$ & $\begin{array}{r}0.039 \\
(1.0 \%) \\
(1.1 \%)\end{array}$ \\
\hline 2 & $\begin{array}{c}25.096 \\
(10.723) \\
(11.013)\end{array}$ & $\begin{array}{l}-5.232 \\
(2.292) \\
(2.348)\end{array}$ & $\begin{array}{c}17.518 \\
(18.936) \\
(19.797)\end{array}$ & $--\cdots$ & --- & $\begin{array}{c}0.041 \\
(1.913)\end{array}$ & $\begin{array}{c}0.136 \\
(1.9 \%) \\
(2.2 \%)\end{array}$ \\
\hline 3 & $\begin{array}{c}12.920 \\
(12.101) \\
(12.264)\end{array}$ & $\begin{array}{l}-3.834 \\
(2.348) \\
(2.387)\end{array}$ & $--\cdot$ & $\begin{array}{c}6.980 \\
(3.298) \\
(3.352)\end{array}$ & --- & $\begin{array}{c}0.055 \\
(1.926)\end{array}$ & $\begin{array}{l}0.042 \\
(0.4 \%) \\
(0.5 \%)\end{array}$ \\
\hline 4 & $\begin{array}{c}12.739 \\
(10.989) \\
(11.537)\end{array}$ & $\begin{array}{l}-3.528 \\
(2.274) \\
(2.371)\end{array}$ & $-\cdots$ & $-\cdots$ & $\begin{array}{c}28.647 \\
(9.514) \\
(10.446)\end{array}$ & $\begin{array}{c}0.110 \\
(1.928)\end{array}$ & $\begin{array}{c}0.146 \\
(<0.05 \%) \\
(<0.05 \%)\end{array}$ \\
\hline 5 & $\begin{array}{c}2.954 \\
(12.729) \\
(13.311)\end{array}$ & $\begin{array}{l}-2.442 \\
(2.330) \\
(2.441)\end{array}$ & $\begin{array}{c}-2.724 \\
(19.431) \\
(20.688)\end{array}$ & $\begin{array}{c}4.763 \\
(3.144) \\
(3.232)\end{array}$ & $\begin{array}{c}27.267 \\
(9.625) \\
(10.614)\end{array}$ & $\begin{array}{c}0.118 \\
(1.946)\end{array}$ & $\begin{array}{c}0.151 \\
(<0.05 \%) \\
(0.1 \%)\end{array}$ \\
\hline 6 & $\begin{array}{l}16.859 \\
(5.706) \\
(5.776)\end{array}$ & $\begin{array}{l}-2.234 \\
(0.990) \\
(1.006)\end{array}$ & $\cdots$ & $\cdots$ & $-\cdots$ & $\begin{array}{c}0.018 \\
(1.900)\end{array}$ & $\begin{array}{c}0.042 \\
(2.3 \%) \\
(2.6 \%)\end{array}$ \\
\hline 7 & $\begin{array}{l}15.662 \\
(5.813) \\
(5.915)\end{array}$ & $\begin{array}{l}-2.992 \\
(1.006) \\
(1.027)\end{array}$ & $\begin{array}{l}28.111 \\
(9.184) \\
(9.488)\end{array}$ & $-\cdots$ & --- & $\begin{array}{c}0.043 \\
(1.946)\end{array}$ & $\begin{array}{c}0.151 \\
(0.1 \%) \\
(0.1 \%)\end{array}$ \\
\hline 8 & $\begin{array}{c}1.137 \\
(7.358) \\
(7.488)\end{array}$ & $\begin{array}{l}-1.082 \\
(1.035) \\
(1.059)\end{array}$ & --- & $\begin{array}{c}7.881 \\
(2.448) \\
(2.505)\end{array}$ & $-\cdots$ & $\begin{array}{c}0.054 \\
(1.948)\end{array}$ & $\begin{array}{c}0.063 \\
(0.1 \%) \\
(0.1 \%)\end{array}$ \\
\hline 9 & $\begin{array}{l}14.003 \\
(5.580) \\
(5.674)\end{array}$ & $\begin{array}{l}-2.805 \\
(0.998) \\
(1.021)\end{array}$ & --- & $\cdots$ & $\begin{array}{l}16.298 \\
(3.925) \\
(4.124)\end{array}$ & $\begin{array}{c}0.091 \\
(2.002)\end{array}$ & $\begin{array}{c}0.175 \\
(<0.05 \%) \\
(<0.05 \%)\end{array}$ \\
\hline 10 & $\begin{array}{c}6.478 \\
(7.259) \\
(7.447)\end{array}$ & $\begin{array}{l}-2.261 \\
(1.073) \\
(1.107)\end{array}$ & $\begin{array}{c}5.098 \\
(11.757) \\
(12.392)\end{array}$ & $\begin{array}{c}3.931 \\
(2.443) \\
(2.527)\end{array}$ & $\begin{array}{l}13.251 \\
(4.536) \\
(4.775)\end{array}$ & $\begin{array}{c}0.100 \\
(2.011)\end{array}$ & $\begin{array}{c}0.195 \\
(<0.05 \%) \\
(<0.05 \%)\end{array}$ \\
\hline
\end{tabular}

Sample period: rows 1 to $5,1959: 2-1978: 9$, rows 6 to $10,1959: 2-1983: 11$. 
Summary Statistics for Excess Bill, Bond and Stock Returns

1959:2-1978:9 Bills Bonds Stock

Ex Post Excess Returns:

\begin{tabular}{lcccc} 
Means & & 0.234 & -1.605 & 3.353 \\
\multicolumn{2}{l}{ Standard deviations } & 0.484 & 25.738 & 49.631 \\
& & & & \\
Correlations & Bills & 1.000 & 0.354 & 0.149 \\
(Covariances) & Bonds & $(4.410)$ & 1.000 & 0.260 \\
& Stock & $(3.579)$ & $(332.125)$ & 1.000
\end{tabular}

Ex Ante Excess Returns (fitted values from Row 5, Table 1):

\begin{tabular}{lcccc} 
Means & & 0.234 & -1.605 & 3.353 \\
\multicolumn{2}{l}{ Standard deviations } & 0.231 & 5.938 & 17.024 \\
& & & & \\
Correlations & Bills & 1.000 & 0.551 & 0.285 \\
(Covariances) & Bonds & $(0.756)$ & 1.000 & 0.864 \\
& Stock & $(1.121)$ & $(87.340)$ & 1.000
\end{tabular}

1959:2-1983:11 Bills Bonds Stock

Ex Post Excess Returns:

$\begin{array}{lcccc}\text { Means } & & 0.378 & -2.485 & 3.896 \\ & & & & \\ \text { Standard deviations } & 0.855 & 43.749 & 51.032 \\ & & & & \\ \text { Correlations } & \text { Bills } & 1.000 & 0.425 & 0.159 \\ \text { (Covariances) } & \text { Bonds } & (15.897) & 1.000 & 0.300 \\ & \text { Stock } & (6.938) & (669.780) & 1.000\end{array}$

Ex Ante Excess Returns (fitted values from Row 5, Table 1):

\begin{tabular}{lcccc} 
Means & & 0.378 & -2.485 & 3.896 \\
\multicolumn{2}{l}{ Standard deviations } & 0.465 & 8.904 & 16.143 \\
& & & & \\
Correlations & Bills & 1.000 & 0.029 & 0.321 \\
(Covariances) & Bonds & $(0.120)$ & 1.000 & 0.778 \\
& Stock & $(2.410)$ & $(111.828)$ & 1.000
\end{tabular}


TABLE 3

Latent Variable Models for Excess Bill, Bond and Stock Returns

Chi-square statistics, degrees of freedom and significance levels:

$1959: 2-1978: 9 \quad 1959: 2-1983: 11$

1 latent variable

bills, bonds and stock $20.431,8,0.9 \% \quad 20.399,8,0.9 \%$

bills and bonds

bills and stock

$11.533,4,2.1 \%$

$3.787,4,43.6 \%$

bonds and stock

$10.630,4,3.1 \%$

$16.181,4, \quad 0.3 \%$

2 latent variables

$8.364,4,7.9 \% \quad 6.339,4,17.5 \%$

bills, bonds and stock

$6.749,3, \quad 8.0 \%$

$3.173,3,36.6 \%$

Coefficient estimates for models with 2 latent variables:

$\begin{array}{lccccl}\text { Dependent } & \text { Constant } & \text { 1-Month } & \text { 2-Month } & \text { 20-Year } & \text { Lagged } \\ \text { Variable } & \text { Rate } & \text { Spread } & \text { Spread } & \begin{array}{l}\text { Excess } \\ 2-\text { Month }\end{array} \\ & & & & \text { Return }\end{array}$

$1959: 2-1978: 9$

\begin{tabular}{|c|c|c|c|c|c|}
\hline Bills & $\begin{array}{c}0.122 \\
(0.097)\end{array}$ & $\begin{array}{l}-0.007 \\
(0.022)\end{array}$ & $\begin{array}{c}1.276 \\
(0.134)\end{array}$ & $\begin{array}{l}-0.046 \\
(0.025)\end{array}$ & $\begin{array}{c}0.119 \\
(0.102)\end{array}$ \\
\hline Bonds & $\begin{array}{l}-5.961 \\
(4.312)\end{array}$ & $\begin{array}{l}-0.073 \\
(0.802)\end{array}$ & $\begin{array}{l}-1.544 \\
(8.216)\end{array}$ & $\begin{array}{c}2.655 \\
(1.431)\end{array}$ & $\begin{array}{c}9.626 \\
(3.832)\end{array}$ \\
\hline Stock & $\begin{array}{l}85 \times \mathrm{fit} \\
87)\end{array}$ & $\begin{array}{l}\text { Bills } \\
\quad(0.9\end{array}$ & $2.252 \mathrm{x}$ & itted Bor & \\
\hline
\end{tabular}

$1959: 2-1983: 11$

$\begin{array}{lccccc}\text { Bills } & 0.040 & 0.028 & 0.915 & -0.096 & 0.225 \\ & (0.103) & (0.022) & (0.198) & (0.043) & (0.076)\end{array}$

$\begin{array}{lllccc}\text { Bonds } & 1.370 & -1.297 & -10.783 & 3.080 & 0.993 \\ & (3.067) & (0.913) & (7.202) & (2.070) & (3.475)\end{array}$

Stock $=40.912 \times$ fitted Bills $+2.639 \times$ fitted Bonds $(30.760) \quad(2.529)$ 
TABLE 5

Single-Beta Models for Excess Returns: Observable Benchmark Portfolio

Row $\begin{array}{ll}\text { Dependent } & \text { Benchmark } \\ \text { Excess } & \text { Portfolio } \\ \text { Return } & \end{array}$

\begin{tabular}{cc}
\multicolumn{2}{c}{ Joint Significance of } \\
Cross-Products & Information \\
Wariables \\
with C without C with C without C
\end{tabular}

\begin{tabular}{|c|c|c|c|c|c|c|}
\hline 1 & Bill & Bond & $0.1 \%$ & $19.6 \%$ & $\begin{array}{c}0.0 \% \\
(0.0 \%)\end{array}$ & $\begin{array}{c}0.0 \% \\
(0.0 \%)\end{array}$ \\
\hline 2 & Bill & Stock & $26.7 \%$ & $93.8 \%$ & $\begin{array}{c}0.0 \% \\
(0.0 \%)\end{array}$ & $\begin{array}{c}0.0 \% \\
(0.0 \%)\end{array}$ \\
\hline 3 & Bond & Bil1 & $0.0 \%$ & $90.2 \%$ & $\begin{array}{c}0.4 \% \\
(2.8 \%)\end{array}$ & $\begin{array}{l}10.0 \% \\
(3.5 \%)\end{array}$ \\
\hline 4 & Bond & Stock & $0.6 \%$ & $7.1 \%$ & $\begin{array}{l}12.9 \% \\
(2.8 \%)\end{array}$ & $\begin{array}{l}27.4 \% \\
(3.5 \%)\end{array}$ \\
\hline 5 & Stock & Bill & $56.9 \%$ & $80.3 \%$ & $\begin{array}{c}0.6 \% \\
(0.0 \%)\end{array}$ & $\begin{array}{c}0.3 \% \\
(0.0 \%)\end{array}$ \\
\hline 6 & Stock & Bond & $0.0 \%$ & $0.3 \%$ & $\begin{array}{c}0.1 \% \\
(0.0 \%)\end{array}$ & $\begin{array}{c}0.1 \% \\
(0.0 \%)\end{array}$ \\
\hline
\end{tabular}

\begin{tabular}{|c|c|c|c|c|c|c|}
\hline 7 & Bil1 & Bond & $0.0 \%$ & $3.3 \%$ & $\begin{array}{c}0.0 \% \\
(0.0 \%)\end{array}$ & $\begin{array}{c}0.0 \% \\
(0.0 \%)\end{array}$ \\
\hline 8 & Bill & Stock & $61.0 \%$ & $57.6 \%$ & $\begin{array}{c}0.0 \% \\
(0.0 \%)\end{array}$ & $\begin{array}{c}0.0 \% \\
(0.0 \%)\end{array}$ \\
\hline 9 & Bond & Bill & $0.0 \%$ & $90.2 \%$ & $\begin{array}{c}0.0 \% \\
(16.8 \%)\end{array}$ & $\begin{array}{c}0.0 \% \\
(29.7 \%)\end{array}$ \\
\hline 10 & Bond & Stock & $0.0 \%$ & $0.0 \%$ & $\begin{array}{c}17.9 \% \\
(16.8 \%)\end{array}$ & $\begin{array}{c}27.3 \% \\
(29.7 \%)\end{array}$ \\
\hline 11 & Stock & Bi11 & $11.5 \%$ & $55.7 \%$ & $\begin{array}{c}1.1 \% \\
(0.0 \%)\end{array}$ & $\begin{array}{c}0.6 \% \\
(0.0 \%)\end{array}$ \\
\hline 12 & Stock & Bond & $0.0 \%$ & $0.3 \%$ & $\begin{array}{c}0.0 \% \\
(0.0 \%)\end{array}$ & $\begin{array}{c}0.1 \% \\
(0.0 \%)\end{array}$ \\
\hline
\end{tabular}

Sample period: rows 1 to $6,1959: 2-1978: 9$, rows 7 to $12,1959: 2-1983: 11$. 
TABLE 6

Single-Beta Models for Excess Returns: Estimated Benchmark Portfolio

$\begin{array}{lcclll}\text { Dependent } & \text { Constant } & \text { 1-Month } & \text { 2-Month } & \text { 20-Year } & \text { Lagged } \\ \text { Variable } & \text { Rate } & \text { Spread } & \text { Spread } & \text { Excess } \\ & & & & \text { 2-Month } \\ & & & & \text { Return }\end{array}$

$1959: 2-1978: 9$

\begin{tabular}{|c|c|c|c|c|c|c|}
\hline $\begin{array}{l}\text { Bills } \\
\text { Beta }\end{array}$ & $\begin{array}{c}0.889 \\
(0.097)\end{array}$ & $\begin{array}{c}0.023 \\
(0.013)\end{array}$ & $\begin{array}{c}0.062 \\
(0.061)\end{array}$ & $\begin{array}{l}-0.025 \\
(0.023)\end{array}$ & $\begin{array}{l}-0.101 \\
(0.029)\end{array}$ & $<0.05 \%$ \\
\hline $\begin{array}{l}\text { Bonds } \\
\text { Beta }\end{array}$ & $\begin{array}{l}-19.643 \\
(15.767)\end{array}$ & $\begin{array}{c}2.193 \\
(2.250)\end{array}$ & $\begin{array}{c}12.216 \\
(11.849)\end{array}$ & $\begin{array}{c}4.917 \\
(4.626)\end{array}$ & $\begin{array}{l}21.410 \\
(5.468)\end{array}$ & $<0.05 \%$ \\
\hline $\begin{array}{l}\text { Stock } \\
\text { Beta }\end{array}$ & $\begin{array}{c}31.409 \\
(28.885)\end{array}$ & $\begin{array}{l}-5.031 \\
(3.824)\end{array}$ & $\begin{array}{l}-95.457 \\
(22.987)\end{array}$ & $\begin{array}{l}13.043 \\
(7.029)\end{array}$ & $\begin{array}{c}61.849 \\
(10.284)\end{array}$ & $<0.05 \%$ \\
\hline $\mathrm{eh}_{z t}$ & $\begin{array}{c}0.009 \\
(0.092)\end{array}$ & $\begin{array}{c}0.040 \\
(0.018)\end{array}$ & $\begin{array}{c}1.021 \\
(0.119)\end{array}$ & $\begin{array}{l}-0.041 \\
(0.022)\end{array}$ & $\begin{array}{c}0.169 \\
(0.073)\end{array}$ & $<0.05 \%$ \\
\hline
\end{tabular}

eh $_{z t}=\underset{(0.0002)}{(0.000 \times \text { Bills }-} \begin{gathered}0.003 \times \text { Bonds }+0.003 \times \text { Stocks } \\ (0.0004)\end{gathered}$

$\mathrm{eh}_{z t}$ Variance $=\underset{(0.057)}{-0.005}+\underset{(0.193)}{0.448} \times$ Expected $\mathrm{eh}_{z \mathrm{t}}$

Chi-square statistic $35.385,16$ degrees of freedom, significance leve1 $0.4 \%$ 
TABLE 6 (CONTINUED)

\begin{tabular}{|c|c|c|c|c|c|}
\hline $\begin{array}{l}\text { Dependent } \\
\text { Variable }\end{array}$ & Constant & $\begin{array}{l}\text { 1-Month } \\
\text { Rate }\end{array}$ & $\begin{array}{l}2 \text {-Month } \\
\text { Spread }\end{array}$ & $\begin{array}{l}20-\text { Year } \\
\text { Spread }\end{array}$ & $\begin{array}{l}\text { Lagged } \\
\text { Excess } \\
2 \text {-Month } \\
\text { Return }\end{array}$ \\
\hline
\end{tabular}

$1959: 2-1983: 11$

$\begin{array}{lcccccc}\text { Bills } & 0.825 & 0.003 & -0.123 & 0.080 & 0.049 & <0.05 \% \\ \text { Beta } & (0.065) & (0.007) & (0.087) & (0.023) & (0.017) & \\ \text { Bonds } & -17.412 & 0.524 & -19.195 & 9.094 & 6.585 & <0.05 \% \\ \text { Beta } & (8.619) & (1.094) & (8.429) & (2.699) & (1.690) & \\ \text { Stock } & 25.639 & -3.117 & -1.692 & 5.058 & 4.970 & <0.05 \% \\ \text { Beta } & (12.038) & (0.955) & (8.617) & (2.343) & (3.048) & \\ \text { eh } & 0.060 & 0.034 & 0.828 & -0.104 & 0.257 & <0.05 \% \\ & (0.092) & (0.015) & (0.183) & (0.028) & (0.069) & \end{array}$

$\mathrm{eh}_{z \mathrm{t}}=\underset{(0.0005)}{(0.007 \times \text { Bills }}-\underset{(0.0004)}{0.008 \times \text { Bonds }}+0.001 \times$ Stocks

$\mathrm{eh}_{z t}$ Variance $=\begin{aligned} & -0.007 \\ & (0.081)\end{aligned}+\underset{(0.273)}{0.524 \times \text { Expected eh }} \mathrm{zt}$

Chi-square statistic $16.717,16$ degrees of freedom, significance leve1 $40.4 \%$ 


\section{BIBLIOGRAPHY}

Belsley, David A., Edwin Kuh and Roy E. Welsch, Regression Diagnostics, Wiley 1980 .

Breeden, Douglas, "An Intertemporal Asset Pricing Model with Stochastic Consumption and Investment Opportunities", Journal of Financial Economics Vol. 7 pp. 265-296, 1979.

Campbe11, John Y. [1984a], Asset Duration and Time-Varying Risk Premia, PhD dissertation, Yale University, 1984.

Campbel1, John Y. [1984b], "Bond and Stock Returns in a Simple Exchange Mode1", National Bureau of Economic Research Working Paper No. 1509,1984 .

Campbel1, John Y. [1984c], "A Defense of Traditiona1 Ḧypotheses about the Term Structure of Interest Rates", National Bureau of Economic Research Working Paper No. 1508, 1984.

Campbe11, John Y. and Robert J. Shiller, "A Simple Account of the Behavior of Long-Term Interest Rates", American Economic Review Vol. 74 No. 2, Papers and Proceedings, pp. 44-48, May 1984.

Chesher, Andrew and Ian Jewitt, "Finite Sample Properties of Least Squares Covariance Matrix Estimators", unpublished paper, University of Bristol, November 1984.

Constantinides, George M., "Admissible Uncertainty in the Intertemporal Asset Pricing Mode1", Journal of Financial Economics Vol. 8 pp. 71-86, 1980 .

Cox, John C., Jonathan E. Ingersoll Jr. and Stephen A. Ross, "A Re-examination of Traditional Hypotheses about the Term Structure of Interest Rates", Journal of Finance Vol. 36 No. 4, pp. 769-799, 1981.

Efron, B., The Jackknife, The Bootstrap and Other Resampling Plans, Society for Industrial and Applied Mathematics, Philadelphia, 1982 .

Engle, Robert F., David M. Lilien and Russell P. Robins, "Estimating Time-Varying Risk Premia in the Term Structure: the ARCH-M Model", unpublished paper, University of California at San Diego, March 1985.

Fama, Eugene F., "Inflation Uncertainty and Expected Returns on Treasury Bills", Journal of Political Economy Vol. 84 pp. 427-448, June 1976.

Fama, Eugene F., "Stock Returns, Real Activity, Inflation and Money", American Economic Review Vol. 71 pp. 545-565, September 1981. 
Fama, Eugene F. [1984a], "The Information in the Term Structure", Journal of Financial Economics Vol. 13 pp. 509-528, 1984.

Fama, Eugene F. [1984b], "Term Premiums in Bond Returns", Journal of Financial Economics Vol. 13 pp. 529-546, 1984.

Fama, Eugene F. and G. William Schwert, "Asset Returns and Inflation", Journal of Financial Economics Vol. 5 pp. 115-146, November 1977 .

Geske, Robert and Richard Rol1, "The Fiscal and Monetary Linkage between Stock Returns and Inflation", Journal of Finance Vol. 38 pp. 1-33, March 1983.

Gibbons, Michael R., "Multivariate Tests of Financial Models: A New Approach", Journal of Financial Economics Vol. 10 pp. 3-27, 1980.

Gibbons, Michael R. and Wayne Ferson, "Testing Asset Pricing Models with Changing Expectations and an Unobservable Market Portfolio", unpublished paper, January 1983.

Hansen, Lars Peter, "Large Sample Properties of Generalized Method of Moments Estimators", Econometrica Vol. 50 No. 4 pp. 1029-1054, July 1982 .

Hansen, Lars Peter and Robert J. Hodrick, "Risk Averse Speculation in the Forward Foreign Exchange Market: An Econometric Analysis of Linear Models", in Jacob A. Frenkel ed. Exchange Rates and International Macroeconomics, University of Chicago Press, 1983.

Hansen, Lars Peter, Scott F. Richard and Kenneth J. Singleton, "Econometric Implications of the Intertemporal Capital Asset Pricing Model", unpublished paper, November 1981.

Hansen, Lars Peter and Kenneth J. Singleton, "Generalized Instrumental Variables Estimation of Nonlinear Rational Expectations Models", Econometrica Vol. 50 No. 5 pp. 1269-1286, September 1982.

Huizinga, John and Frederick S. Mishkin, "The Measurement of ExAnte Real Interest Rates on Assets with Different Risk Characteristics", unpublished paper, University of Chicago, 1984.

Keim, Donald B. and Robert F. Stambaugh, "Predicting Returns in the Stock and Bond Markets", unpublished paper, Wharton School, 1984.

LeRoy, Stephen F. [1982a], "Expectations Models of Asset Prices: A Survey of Theory", Journal of Finance Vol. 37 No. 1 pp. 185-217, March 1982.

LeRoy, Stephen F. [1982b], "Risk-Aversion and the Term Structure of Real Interest Rates", Economics Letters Vol. 10 No. 3-4 pp. 355-362, 1982 . 
Mackinnon, James G. and Halbert White, "Some Heteroskedasticity Consistent Covariance Matrix Estimators with Improved Finite Sample Properties", unpublished paper, Queen's University, December 1984.

Mankiw, N. Gregory and Lawrence H. Summers, "Do Long-Term Interest Rates Overreact to Short-Term Interest Rates?", Brookings Papers on Economic Activity $1984: 1$ pp. 223-242, 1984.

Merton, Robert C., "An Intertemporal Capital Asset Pricing Model", Econometrica Vol. 44 pp. 867-887, September 1973.

Merton, Robert C., "On Estimating the Expected Return on the Market", Journal of Financial Economics Vol. 8 pp. 323-361, 1980.

Pindyck, Robert S., "Risk, Inflation and the Stock Market", American Economic Review Vol. 74 No. 3 pp. 335-351, June 1984.

Salomon Brothers Inc., An Analytical Record of Yields and Yield Spreads, New York, 1983.

Schwert, G. William, "The Adjustment of Stock Prices to Information about Inflation", Journal of Finance Vol. 36 pp. 15-29, March 1981 .

Shiller, Robert J., John Y. Campbell and Kermit L. Schoenholtz, "Forward Rates and Future Policy: Interpreting the Term Structure of Interest Rates", Brookings Papers on Economic Activity 1983:1 pp. $173-217,1983$.

Startz, Richard, "Do Forecast Errors or Term Premia Really Make the Difference Between Long and Short Rates?", Journal of Financial Economics Vol. 10 pp. 323-330, November 1982.

White, Halbert, "A Heteroskedasticity-Consistent Covariance Matrix Estimator and a Direct Test for Heteroskedasticity", Econometrica Vol. 48 No. 4 pp. 817-838, May 1980.

White, Halbert, Asymptotic Theory for Econometricians, Academic Press, 1984. 